An Annotated Translation into English of the Ratnamãa ãvadãna with a Critical Introduction

Rev. Gangodawila Chandima 1303 HU2010001

Thesis submitted to the University of Sri Jayewardenepura for the award of the Degree of Doctor of Philosophy in Sanskrit on May 20, 2015 
"The work described in this thesis was carried out by me under the supervision of Prof.Walter Marasinghe and Prof.Saman Ranasinghe and a report on this has not been submitted in whole or in part to any university or any other institution for another Degree/Diploma"

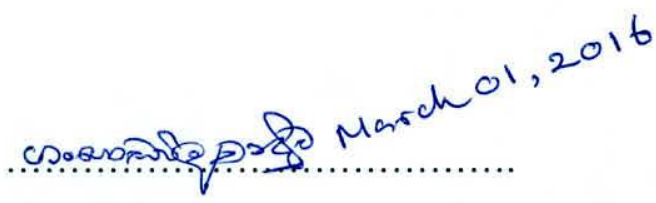

Rev. Gangodawila Chandima

"We certify that the candidate has made all the required corrections, additions and amendments to the thesis taking into account the comments and suggestions made by examiners"

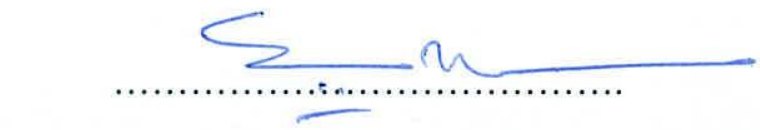

Prof.Walter Marasinghe (External Supervisor)

Prof. E. W. Marasinghe, B.A. Hons., Ph.t Justice of the Peace (Whole Island) Reg. Na 2000/07/ N P W W $/ \mathrm{B} / 259$ No. 129 D/1, Prajamandala Foad, Hedigama, Piliyandala.
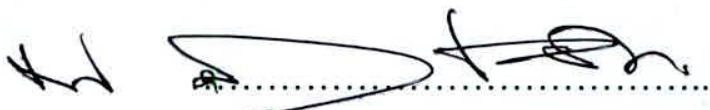

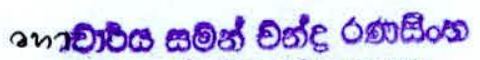

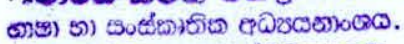
Prof.Saman Ranasinghe (Internal Superviso

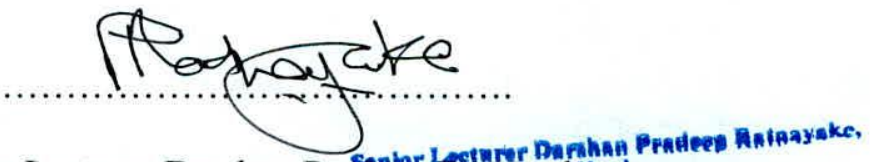

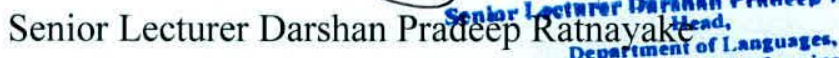
Cultural Studies and Performing Arts.

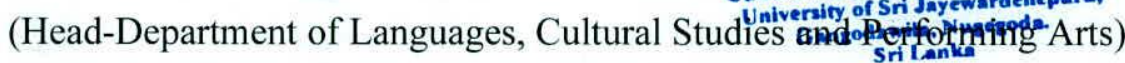




\section{TABLE OF CONTENTS}

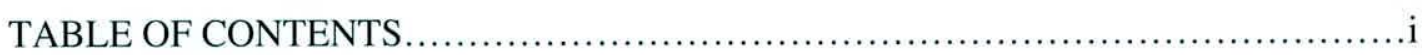

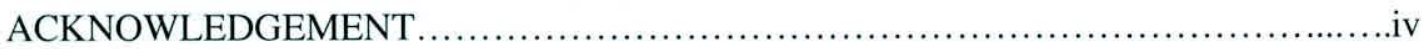

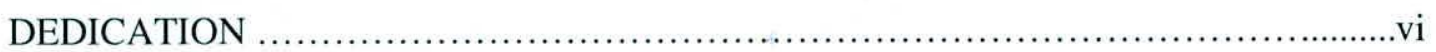

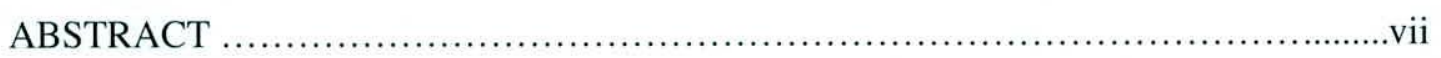

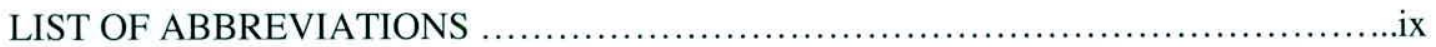

CHAPTER 1. CRITICAL INTRODUCTION TO THE RATNAMĀLĀ VADĀNA ...............1

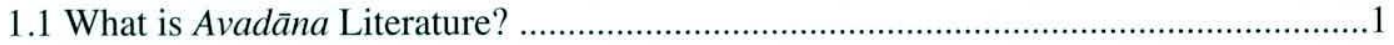

1.1.1 Cultural Usage of the Avadāna Texts .................................................................

1.1.2 Avadāna Texts outside the Sanskrit Canon ...........................................................

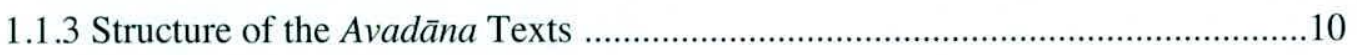

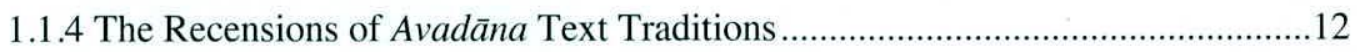

1.1.5 Correlation between the Avadāna and Jātaka Texts ............................................12

1.1.6 Distinction between the Avadāna and Avadānamālā .......................................16

1.1.7 Importance of the Avadāna for Contemporary and Future Scholarship ..............17

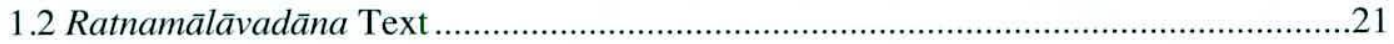

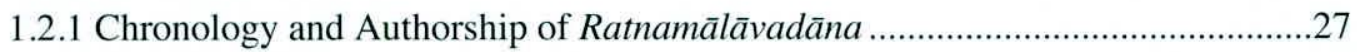

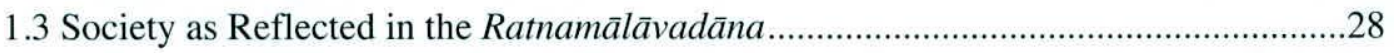

1.3.1 Ratnamālāvadāna as a mood of Mercantile Buddhism .......................................28

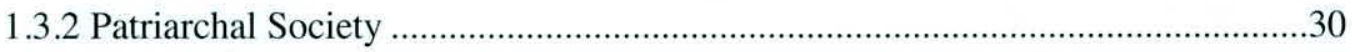

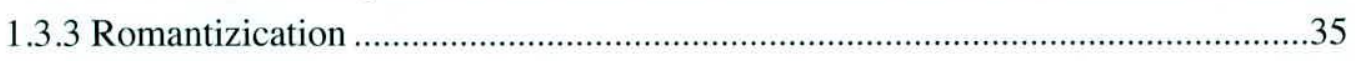

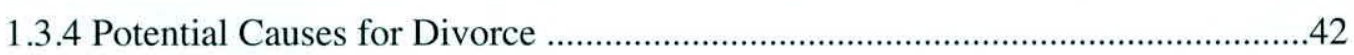

1.3.5 Conception and Propitiation of Deities .................................................................4

1.3.6 Parental Perspective about their Children's Ordination .....................................46

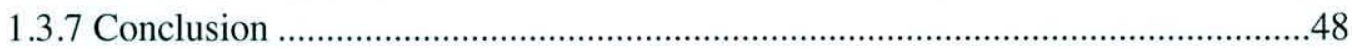

1.4 Doctrinal Teachings as given in the Ratnamālāvadāna ...........................................49

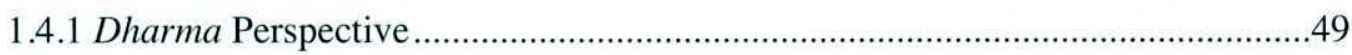

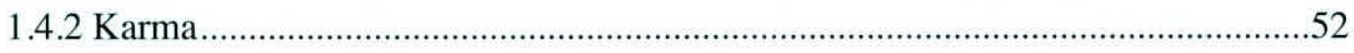

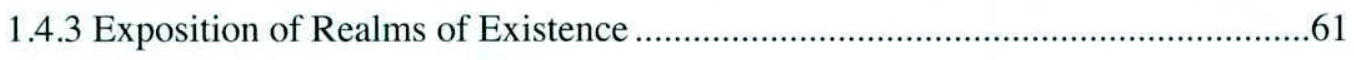

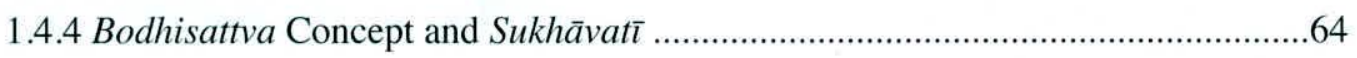




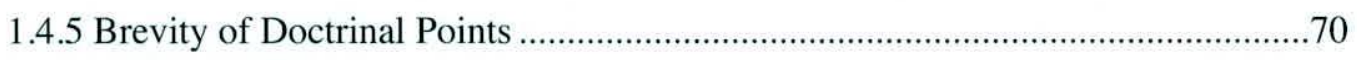

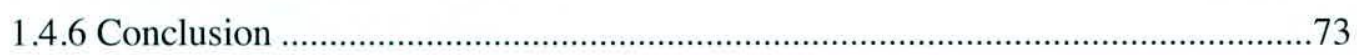

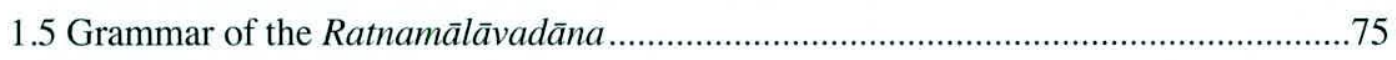

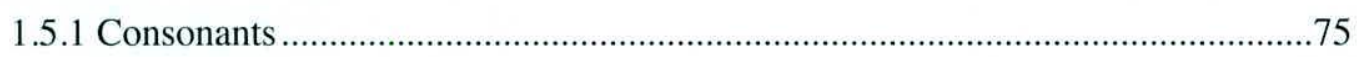

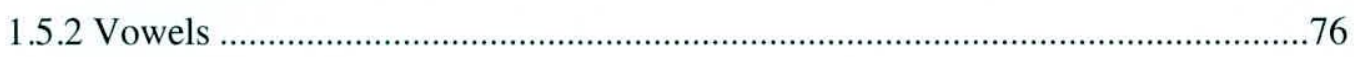

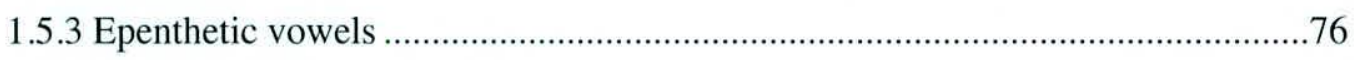

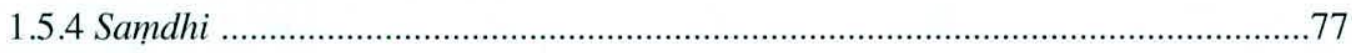

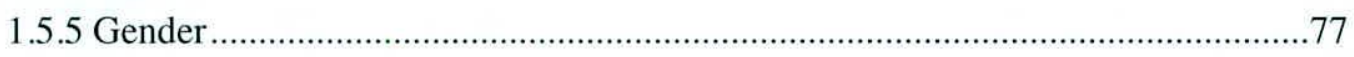

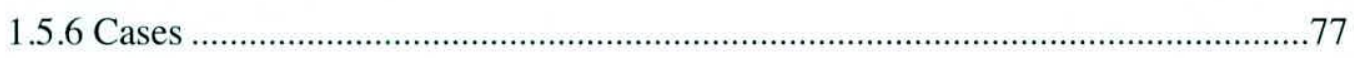

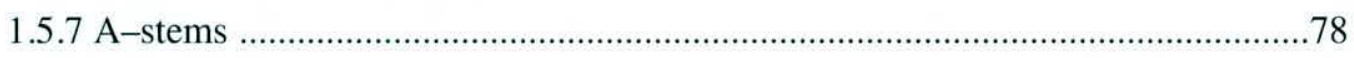

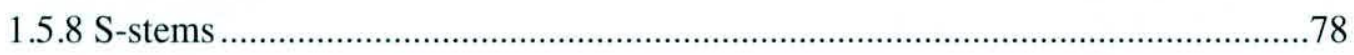

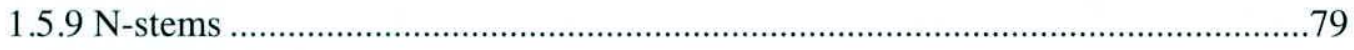

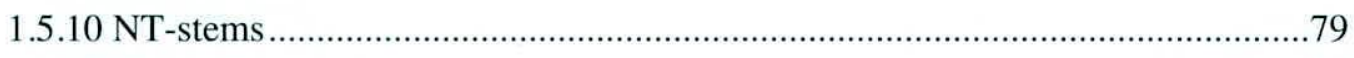

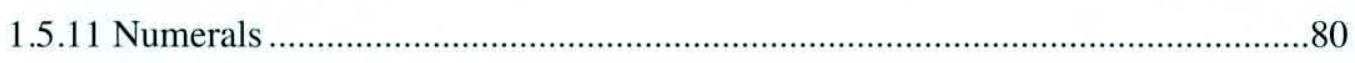

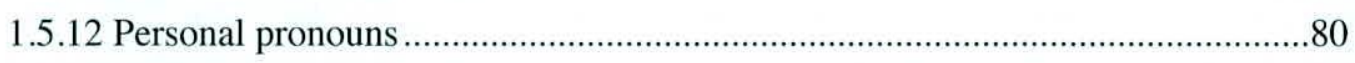

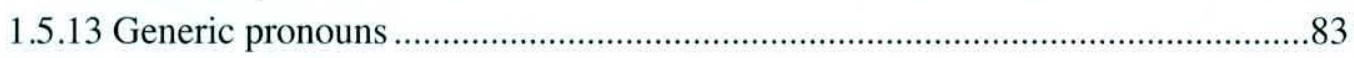

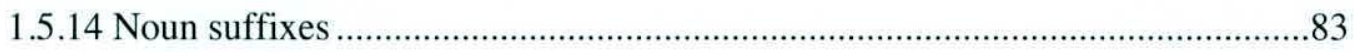

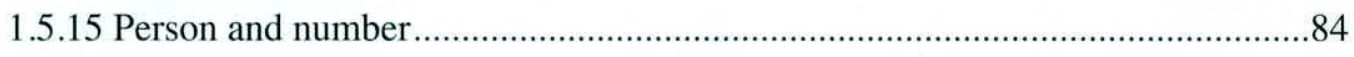

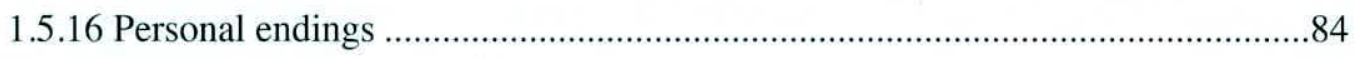

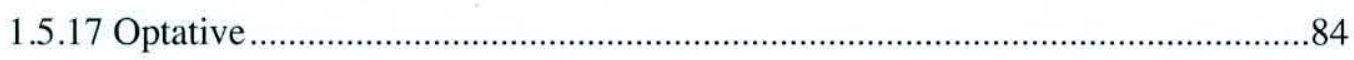

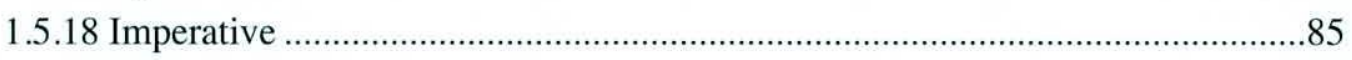

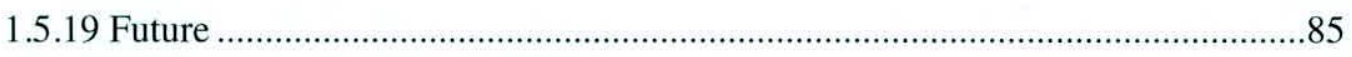

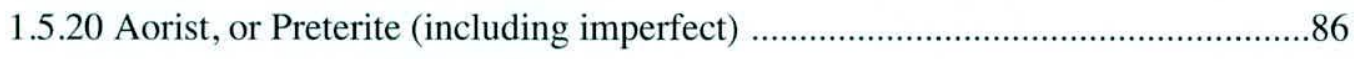

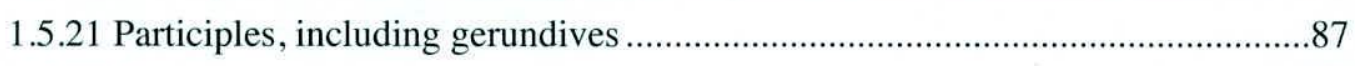

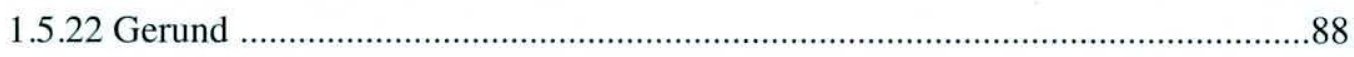

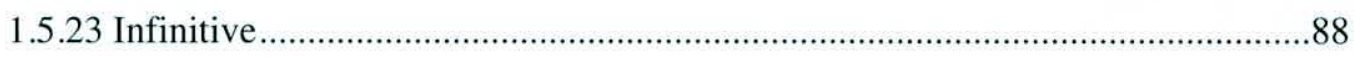

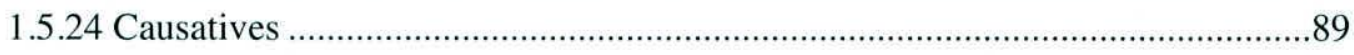

1.5.25 Special use of $b h \bar{u}$; periphrastic verbal expressions (cf.Edgerton 41.5) ...........90

1.5.26 Constructions with mā (cf.Edgerton 42.5) ..................................................90

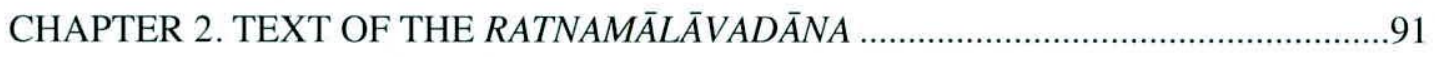

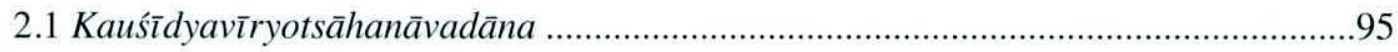

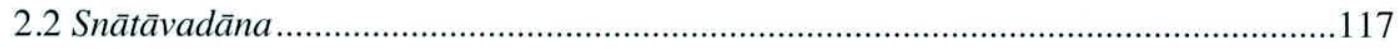

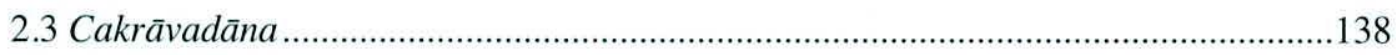

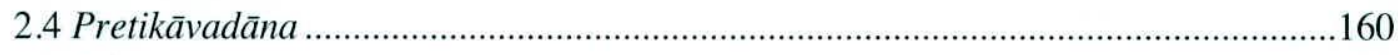

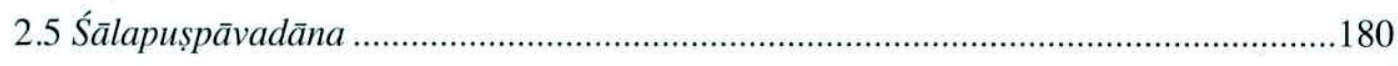

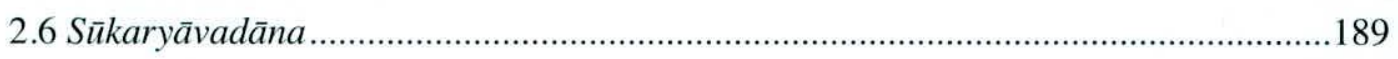




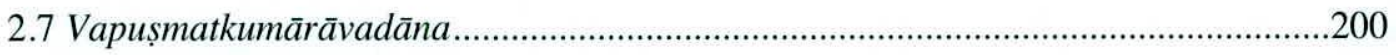

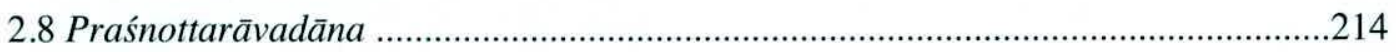

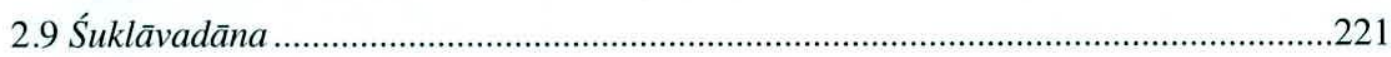

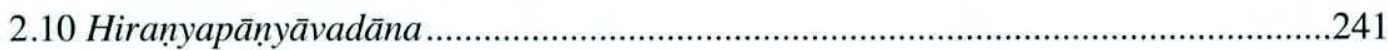

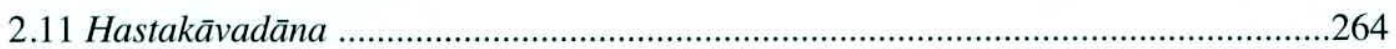

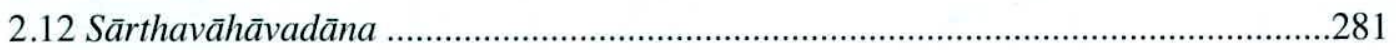

CHAPTER 3. ANNOTATED ENGLISH TRANSLATION OF THE

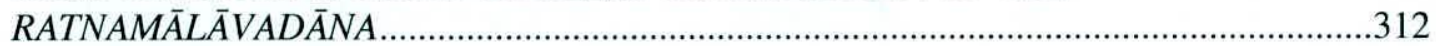

3.1 Avadāna of Valor and Courage of the Indolent ........................................................312

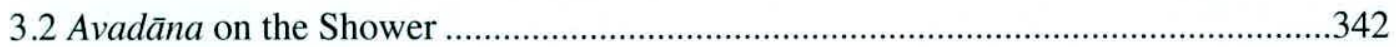

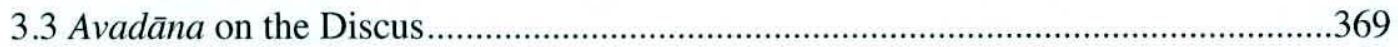

3.4 Avadāna concerning a Goblin.............................................................................398

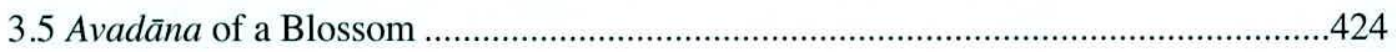

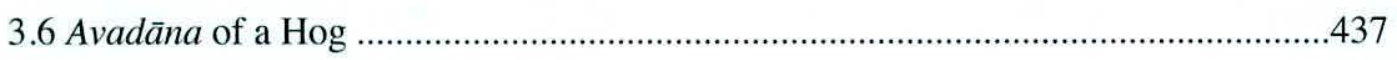

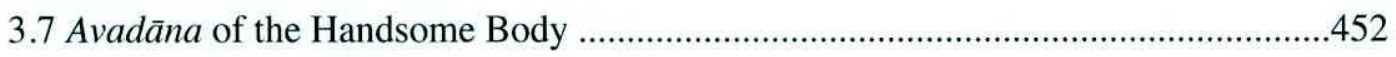

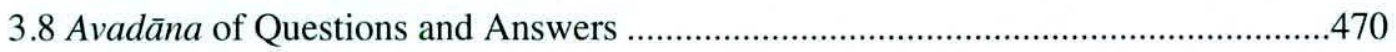

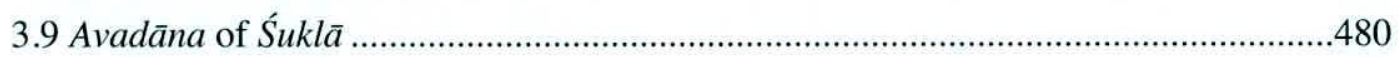

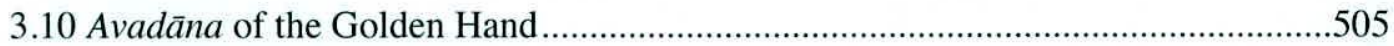

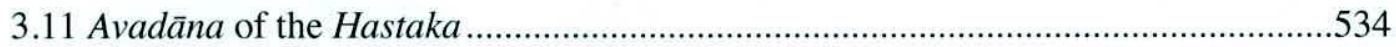

3.12 Avadāna of the Travelling Merchant ………………………………………….....55

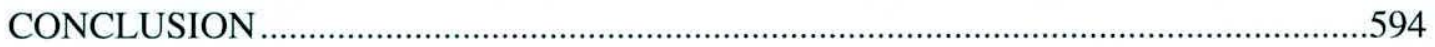

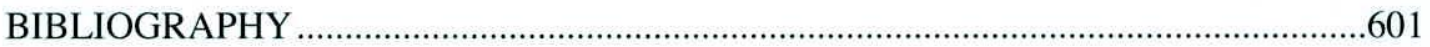




\section{ACKNOWLEDGEMENTS}

This dissertation would not have been possible without the assistance of a number of people. Before naming them, I would also like to say a few words about how I became interested in Sanskrit and eventually pursued my PhD studies in Buddhist Sanskrit.

I began learning Sanskrit as a novice Buddhist monk as early as 1997. Learning Sanskrit and studying the Devanāgarī characters was a fascinating challenge and I wanted to explore the fundamentals of the language in greater detail. I was able to complete my monastic school days (pirivena) by passing the Royal Pundit examination at the age of 19 (in 2003), and then began my four-year undergraduate studies at the University of Sri Jayewardenepura in 2004.

During my undergraduate studies, from 2004 to 2008, I explored several areas of interest, and with guidance from the teaching panel, comprising Dr Maduruoya Dhammissara, Ven Meepitiye Seelaratana, Prof Walter Marasinghe, Prof S Weeratunga, and Prof Saman Chandra Ranasinghe, I was able to extend my knowledge of Sanskrit. I thank them for their guidance and encouragement. In particular, I thank Prof Marasinghe, a co-supervisor of this $\mathrm{PhD}$ dissertation and my supervisor during my $\mathrm{BA}$ Honours dissertation, and Prof Saman Ranasinge, the other co-supervisor, who helped me to see many horizons, not only for my studies but also for life in general. I know I asked them many questions while I was out of the country and I appreciate their support. I will always remember their valuable and enjoyable lessons on the Vedas, brāhmanas, and upanișad texts, and on classical Sanskrit works like Raghuvaṃsa and Meghadūta or the epics, Rāmāyana and Mahābhārata. I I would also like to extend 
my thanks to Pradeep Ratnayake, the Head of the Department of Languages, Cultural Studies, and Performing Arts and all other faculty members for keeping me optimistic about the outcome of this research. Moreover, I owe a debt of gratitude to the board of humanities, Faculty of Graduate Studies, and to Sriyanganie Mendis, Deputy Registrar of the FGS and the other staff members who helped me in administrating my $\mathrm{PhD}$ studies.

As I am now winding up my doctoral dissertation, which was begun in late-2010, I would like to thank my parents and my siblings for their kindness and support that helped to make my $\mathrm{PhD}$ studies enjoyable.

When I arrived in Canada in late-2011, I was able to study many relevant books and articles and had access to online resources from the University of British Columbia where I began working as the Buddhist chaplain. The Canadian academic environment has been extremely beneficial and has helped me with my advanced studies in both Sanskrit and Buddhism. I appreciate those who taught me about the openness, flexibility, respect, and liberal thinking that is prevalent in Canada. I thank my friends and well-wishers who helped me in many ways so that I would be able to successfully complete this massive task. 


\section{DEDICATION}

To my parents and siblings 


\title{
An Annotated Translation into English of the Ratnamālāvadāna with a Critical Introduction
}

\author{
Rev. Gangodawila Chandima
}

\begin{abstract}
Ratnamālāvadāna (RMV) is an avadānamalā text which extolls the significance of both the immediate and post-immediate benefits of respecting the triple gems (Triratna). The text belongs to the Sarvāstivāda School. All of the narrations occur between Upagupta and King Aśoka. Although the text, as given in the manuscripts, includes thirty-eight narrations, I have selected only the first twelve, which represents in the MS (A) manuscript used by Takahata for his edition and remarked by Rajendralala Mithra.
\end{abstract}

This dissertation primarily embodies the first ever annotated English translation of the RMV (Narrations 1-12) with a critical introduction. Although Mahendra Lal Das translated only the second avadāna of the RMV "Cakrāvadana" into English, he had not been able to make any annotated English translation or a critical study of the text. The only document regarding the text which was available to scholars was the Kanga Takahata's edition, which was published in 1954 under the sponsorship of the Harvard Yenching Institute of Cambridge. Therefore, the main purpose of my research is to prepare the first ever annotated English translation of the RMV (Narrations 1-12) for those who will be interested to study the work in English. 
Turning to the contents of the research, I have first given an overview of the avadāna literature which included the topics, such as use of the term avadāna, different avadāna texts, structure of avadāna texts, correlation between avadāna and apadāna and how instrumental is avadāna literature for the contemporary and future scholarship. Then, I delved into an introduction of the RMV text and its chronology. After that, I opened my discussion about the most overriding aspects of the RMV such as the society and doctrine. It was also noted that the society of the RMV can be used to elicit lot of trade customs and societal beliefs of the then society which could not been seen in the similar avadāna or avadānamālā texts. In the study of the doctrinal points, I was able to delineate the RMV text as being very similar to many other avadānamālā texts based on the simple and complex dharma matters. Then, I gave a comprehensive study of the grammatical points of the text, in accordance with the rules of the Buddhist Hybrid Sanskrit Grammar and Dictionary prepared by Franklin Edgerton. In the chapter two, the Romanized Text of the RMV (I-XII) was given as transcribed by Kalus Wille of the University of Gottingen. Please note that I have given the text in Romanized script as Takahata himself has provided his version of the text in Roman characters. Chapter Three forms the annotated English translation of the RMV. In translating the text, care has been taken to be with the style and the nature of the story. 


\section{LIST OF ABBREVIATIONS}

\begin{tabular}{|c|c|}
\hline AN & Añguttaranikāya \\
\hline Av & Avadānaśataka \\
\hline Bbh & Bodhisattvabhūmi \\
\hline BV & Buddhavamsa \\
\hline DhpA & Dhammapadatthakathā \\
\hline Dharmas & Dharmasamgraha \\
\hline Divy & Divyāvadāna \\
\hline DA & Dīghanikāyatțhakathā \\
\hline $\mathrm{Gv}$ & Gandavyūha \\
\hline $\mathrm{Kv}$ & Kāraṇdavyūha \\
\hline Lan்k & Lankāouatārasūtra \\
\hline LV & Lalitavistara \\
\hline Māy & Mahā-Mayūri \\
\hline Mmk & Mañjuśrīmūlakalpa \\
\hline $\mathrm{MN}$ & Majjhimanikāya \\
\hline $\mathrm{Mv}$ & Mahāvastu \\
\hline Mvy & Mahāvyutpatti \\
\hline RMV & Ratnamālāvadāna \\
\hline Sādh & Sādhanamālā \\
\hline Samādh & Samādhirājasūtra \\
\hline SP & Saddharmapundarīka \\
\hline Suv & Suvarṇabhāsottamasūtra \\
\hline VT & Vinaya Texts \\
\hline
\end{tabular}




\section{CHAPTER 1. CRITICAL INTRODUCTION TO THE RATNAMĀLA $V A D \bar{A} N A$}

Before moving to a critical study of the Ratnamālāvadāna (hereafter, RMV), one should first consider what avadāna means in order to understand the scope of what I will cover in this chapter. The most recent doctoral dissertation of the avadāna was completed by Tyson (2013), at Cornell University, New York. According to Tyson, a number of key questions need to be addressed when studying the general literature on the avadāna. For instance, what is characteristically seen in the genre, what are the semantics of the word, and what assumptions do scholars and other readers hold for its use in Buddhist scholarship? Second, what makes the study of the avadāna so important for contemporary and future scholarship? What insights can be gained from this kind of study, in terms of further understanding of the avadāna literature? Therefore, I will begin with a thumbnail sketch of the avadāna literature (Sharma, 1985), from the details of primary sources and from the contributions of modern scholars, before moving to a critical study of the RMV.

\subsection{What is Avadāna Literature?}

The etymology of avadāna seems to have two main explanations, which were proposed by scholars such as J.S. Speyer and Max Müller. Speyer (1958) initially held the view that the term reflected a manifestation of segregation and glorious achievements (object of a legend) at a later time, including illustrious actions or heroically performed feats. 
Speyer describes the term avadāna as used to denote illustrious actions and feats in the Classical Sanskrit works:

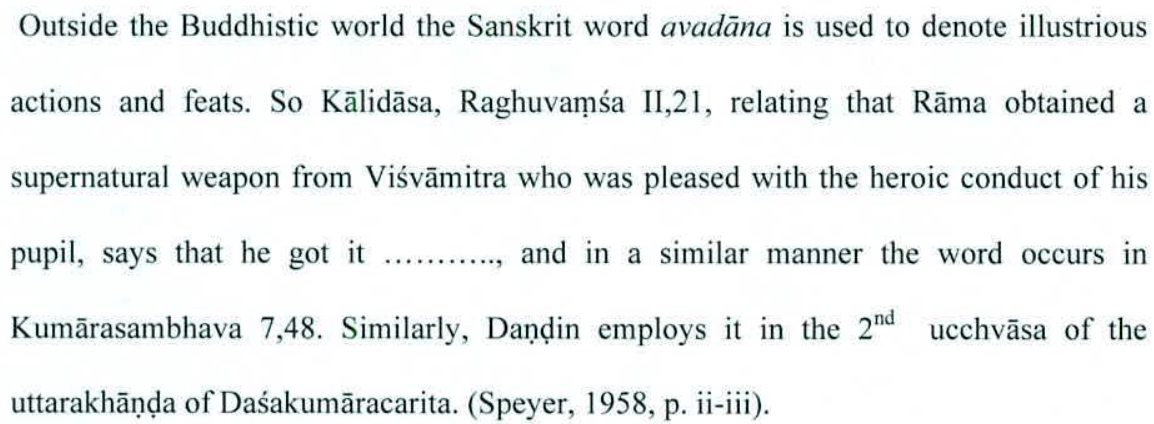

This seems to be the case when considering the vast majority of books written and compiled outside Buddhist literature, in Sanskrit, which were formally identified as Buddhist Hybrid Sanskrit by Edgerton (1970). Nevertheless, this claim contradicts the Buddhist Hybrid Sanskrit works, as revealed in presentations of the karma and vipäka ideologies. Almost all avadāna scholars, including Tyson, seem to have forgotten the role played by vipāka in studies of the subject. Therefore, in understanding the term avadāna, it would be worthwhile to know the vipāka perspective of the avadāna texts. One of the classical lexicographers, Amarasimha places the meaning of the term avadāna as karmavrttam, which means stories of karmas. Given the deeper meaning of illustrious actions, the word karmavrttam can also be taken to imply illustrious or adventurous actions (Sastri, 1945). Speyer (1958) was also of the opinion that karma can certainly have vipāka perspectives. According to Tatelman (2000):

Hence, we find the pervasive doctrinal terms, karma-phala, 'the fruits of actions' and karma-vipaka, 'the ripening of actions,' both of which denote that morally or religiously significant actions in one birth determine or at least influence circumstances in later births. (Tatelman, 2000, p. 5). 
In addition, based on Speyer's interpretation, Maurice Winternitz (1972) added that the avadāna could also refer to noteworthy deeds, and more suitably, heroic acts or feats. Therefore, Speyer is the first to interpret that the meaning of avadāna refers to adeventurous or heroic acts. Other scholars, like E.J. Thomas (1933) and P.L. Vaidya (1958) have largely concurred with the definition of the term as referring to "glorious achievements" or a heroic story. The idea of the heroic story entails a "good, illustrious, heroic or noble act.” Monier-Williams (Monier-Williams, Leumann \& Cappeller, 1899) and Hermann Grassmann (1964) mention the term avadāna in two different contexts. Monier-Williams (Monier-Williams, Leumann \& Cappeller, 1899) and Hermann Grassmann (1964) mention the term avadāna in two different contexts. Monier-Wiliams translates it to mean a great or glorious achievement, while Grassmann translates $a v a+d \bar{a}$ in the German language to mean befrieedigen (to give pleasure) and 'beschenken' (to present).

Max Müller's (1881) interpretation of the term's derivation is based on ava+day (to cleanse, to purify). He goes on to suggest that the word could also mean a legend, originally a pure and virtuous act... and afterwards, a sacred story, and possibly also a narration that improves the purification of mind. Interestingly, this idea is well supported by Kanga Takahata (1954), who observed that all of the avadāna literature emphasizes purification of mind:

These are the main theories put forward; though one cannot reach any rapid conclusions about the original meaning of avadāna, yet it seems beyond doubt that the central idea underlying avadāna literature is in north and south alike, the purification of the mind. It is explained in many places in Buddhist literature to make various offerings and perform acts of worship to the Buddha is to purify the mind," (Takahata, 1954, p. xxii). 
Also Takahata goes on to say how he understands the term in the Chinese Buddhist context.

"Let us consider next sense-changes of this word in the Chinese translations, thus:

In.........., it states, with actual examples, that the word apadāna is word-like (that is, ordinary) soft and shallow words...........; it says that there are two kinds of the one is likely to refer to itivuttaka, and the other is

named (karmaic causations appeared in tripițaka and mahāyāna) and it gives 'examples', but the account is not clear and difficult to follow. Next, in we find the word avadāna explained as a narrative sequence of causation as one finds in the sūtra. The wise talk in sequence, sense, and explanations; there is no confusion, and this is what is known as avadāna. (Takahata, 1954, p. xxii).

Joel Tatelman (1954) suggests an agricultural context for the term in a thorough study of the nexus between avadāna and karma. In his treatment of the term, the moral causality of volitional acts are deeds that one 'sows,' in a given birth, which then 'bear fruit' or are 'harvested.' Products become the results in subsequent births. Tatelman states:

By a process of semantic development which, at least for Pāli, has been clearly delineated, this agricultural sense of the term became identified with the central Buddhist doctrine of karman, the moral causality of volitional action, in which the deeds one 'sows,' performs, in a given birth, 'bear fruit' or are harvested,' produce their results, in subsequent births. In the predominantly agricultural societies of ancient and mediaeval South Asia, employing such universally understood concepts as doctrinal terms made perfect sense. (Tatelman, 2000, p. 5).

Tatelman's view can be combined into the final interpretation of the term. The Pāli canon (Carpenter, 1910; Cutler, 1994) often notes that engaging in karma is like 